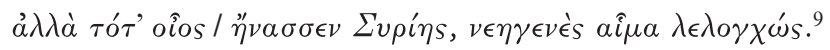

$\nu \epsilon \eta \gamma \epsilon \nu \epsilon^{\prime}$ is unmetrical and so R. Stephanus suggested the spelling $\nu \epsilon \iota \eta \gamma \epsilon \nu \epsilon^{\prime}$. There is no evidence for the word so spelled, but $\epsilon \iota$ for $\epsilon$ for metrical purposes is not unusual. Most commentators recognize that $\nu \epsilon \iota \eta \gamma \epsilon \nu \epsilon ́ s$ is hard to explain in context. A variety of explanations exist, for example, 'possessing newborn blood', that is, having very young children. ${ }^{10}$ But, as the immediately following lines show, his children are of marriageable age. Gifford thinks it refers to new-born sons, presumably born many years after his daughters, and thus explains why he rules alone. But, one presumes, he would rule alone even if his male children were grown. Equally important, it is not at all clear that the Greek can bear this sense; the expression $\alpha \hat{i} \mu \alpha \lambda \epsilon \lambda o \gamma \chi \omega_{\text {s }}$ refers to ancestors, not to descendants (e.g. Lucian, Alex. 11). Lloyd-Jones and Parsons print the transmitted text and obelize.

It is time to resurrect Ludwich's emendation $\epsilon \dot{\eta} \eta \gamma \epsilon \nu \epsilon^{\prime}$. Nearly all scholars ignore it completely. If it is ever mentioned, it is only to be dismissed out of hand, for example, with Holladay's ${ }^{11}$ 'less apt' and that is it. ${ }^{12}$ In fact, it gives good sense, is contextually appropriate, and its corruption is easily explained. The phrase $\epsilon \dot{v} \eta \gamma \epsilon \nu \dot{\epsilon} s$ aî $\mu \alpha$ $\lambda \epsilon \lambda o \gamma \chi \chi^{\omega} s$ means straightforwardly, 'He possessed a distinguished lineage.' Essentially the same sense is present in a very similar phrase at the Orphic Argonautica 81, when Jason describes himself, $\pi \alpha \nu \epsilon^{\prime} \xi o \chi o \nu$ aî $\mu \alpha \lambda \epsilon \lambda \circ \gamma \chi \omega_{s}$, 'I possess a pre-eminent lineage.'

The corruption of $\epsilon \dot{v} \eta \gamma \epsilon \nu \epsilon^{\prime}$ to $\epsilon \nu \eta \gamma \epsilon \nu \epsilon S$ was simple and the inversion of $\epsilon \nu$ to $\nu \epsilon$ to give a real word may have been inevitable, even immediate. ${ }^{13}$

University of Illinois, Urbana

HOWARD JACOBSON doi:10.1017/S0009838807000321

9 P. 361.

10 E.g. E. H. Gifford, Eusebii Pamphili Evangelicae Praeparationis Libri XV, vol. 3.1 (Oxford, 1903), 458, 'who alone o'er Syria ruled, his sons as yet new-born'; K. Mras, Eusebius Werke: Die Praeparatio Evangelica, vol. 8.1 (Berlin, 1954), 513, ap. crit., 'dessen Kinder noch jung waren'. See Holladay (n. 1), 166-7 for other attempts at making sense of the line.

11 Holladay (n. 1), 166.

12 Ludwich (n. 2), 4. Ludwich was in some degree responsible for the neglect of his emendation, since he simply printed it in his text and said not one word in its defence, limiting himself to a statement that $\nu \epsilon \iota \eta \gamma \epsilon \nu \epsilon ́ s$ did not give sense (p. 5).

${ }^{13}$ I am indebted to David Sansone for helpful discussions about these texts. I am also grateful to $C Q$ 's referee for valuable comments and criticisms.

\title{
ALICARIA IN PLAUTUS, FESTUS AND POMPEII
}

Near the beginning of Plautus' Poenulus, the virtuous prostitute Adelphasium, who will turn out to be freeborn, attempts to dissuade her less respectable sister Anterastilis from going to the temple of Venus for a festival in honour of the goddess. Adelphasium's reluctance to be present at these sacrifices arises from her disgust at the crowd that will be in attendance: common prostitutes, the sort of women who smell bad and try to cover it up with cheap perfume, the type who go with millers/ bakers and slaves rather than respectable free clients: 


\author{
AD. Ma- \\ neat pol. mane: \\ Turbast nunc apud aram. an te ibi vis inter istas \\ vorsarier \\ Prosedas, pistorum amicas, reliquias alicarias, \\ Miseras, schoeno delibutas, servolicolas sordidas, \\ Quae tibi olant stabulum st $<\mathrm{r}>$ atumque, sellam et ses- \\ sibulum merum, \\ Quas adeo hau quisquam umquam liber tetigit neque \\ duxit domum, \\ Servolorum sordidulorum scorta diobolaria?
}

Although the speech seems to refer to prostitutes throughout, the meaning of the phrase reliquias alicarias is not immediately apparent. The problem is alicarias. ${ }^{2}$ It occurs only five times in extant Latin. ${ }^{3}$ It is an adjectival form, alicarius, $a$, um (OLD s.v.), derived from the noun alica, a popular type of grain used as porridge. Thus, at its most basic level, alicaria means 'connected with alica'. From the context of the passage and the testimony of Festus (discussed below) it has generally been thought that alicaria could function as a substantive meaning 'prostitute'. ${ }^{4}$ In theory then alicaria was a term that came to be applied to a prostitute who solicited customers outside a mill or bakery. She would have been designated an alicaria from her connection to an alicarius, a miller/baker who dealt primarily in alica. Adams, however, correctly pointed out that, from a strict, grammatical point of view, this is an impossible interpretation of the word in Plautus: alicarias is operating as an adjective modifying reliquias, and as an adjective it must mean 'related to alica', not 'related to alicarii'. ${ }^{5}$ Adams proposed that the sexual connotation of the word arose from activities associated with the preparation of alica:

The metaphors of grinding, milling, crushing etc. applied to sexual intercourse were commonplace ... Hence the implication is 'you are (like) the remnants of alica after it has been

1 This is from the Teubner text of Goetz and Schoell.

2 The primary meaning of reliquiae is 'that which remains after some process of reduction, the remnants, remains' ( $O L D$ s.v.), and in Plautus this almost always refers specifically to left-over food. Although clearly being used metaphorically here it has caused some consternation of its own. Perhaps in an attempt to work around some of that difficulty Lindsay opted for the reading reginas (from the Codex of Turnebus) in place of reliquias. Yet the connotation of reliquiae in Plautus fits well here. Adelphasium seems to be making use of the lower-class associations of the word. In all the examples from Plautus where reliquiae does refer to food it is the meal of a slave or parasite. Throughout the play Adelphasium emphasizes that she and her sister are of finer birth and character than their present situation as slaves might suggest. The use of reliquias, especially as an object of desire for characters of inferior status, brings out the distinction Adelphasium is drawing between herself and the common prostitutes who attend the festival.

3 Plaut. Poen. 266 (alicarias); Lucil. 496 (halicarius); Festus 7 L (alicariae and alicariorum); CIL 4.4001 (halicaria). Charisius (Gramm. p. 123, lines 8-12) remarks that according to Verrius Flaccus alica was pronounced without an ' $\mathrm{h}$ ' but he goes on to cite halicarius in Lucilius. According to V. Väänänen, Introduction au Latin vulgaire (Paris, 1964), 57, there is frequent variation, especially for agricultural vocabulary, between aspirated and unaspirated spellings. Thus, halicaria at CIL 4.4001 is an alternative spelling for alicaria.

4 K. Schneider, 'Meretrix', $R E$ 15.1.1019; H. Herter, 'Die Soziologie der antiken Prostitution im Lichte der heidnischen und christlichen Schrifttums', JbAC 3 (1960), 70-111, at 74-5; the OLD describes alicaria as a 'quasi-sb., of prostitutes'; G. Maurach, Der Poenulus des Plautus (Heidelberg, 1988²), 85, understood the entire phrase to refer to prostitutes ignored even by the miller's slaves.

5 J. N. Adams, 'Words for “prostitute” in Latin', RhM 126 (1983), 321-58, at 336. 
ground', i.e. you have suffered fututio in the manner that alica is ground'. There is implied here a graphic image for intercourse, but alicaria does not mean 'prostitute'. ${ }^{6}$

It may well be that Plautus was relying on his audience to make this specific metaphorical connection, but the later appearances of alicaria suggest that it did eventually became the general equivalent of 'prostitute'. ${ }^{7}$

Festus states the following:

Alicariae meretrices dicebantur in Campania solitae ante pistrina alicariorum versari quaestus gratia, sicut hae, quae ante stabula sedebant, dicebantur prostibula $(7 \mathrm{~L})$.

This is a clear declaration that prostitutes were called alicariae because of their habit of lingering in front of mills or bakeries, where they could presumably find a regular stream of customers. Adams rejects the evidence of Festus on the grounds that it looks like an interpretation of the Plautus passage in question. ${ }^{8}$ Yet Adams' mistrust of Festus' information is excessive. While it is extremely likely that Festus had his eye on Plautus when defining alicaria (he later acknowledges Plautus as his source for proseda and line 266 of the Poenulus is the only place in the entire Plautine corpus where the word appears), it is not necessary to conclude that Festus came to the passage in the Poenulus with no independent knowledge of the word. The key detail is his reference to Campania. There is no suggestion of Campania in Plautus' play. It takes place in Calydon. And we know that Campania was an important region for the cultivation of alica. Pliny states that because of alica Italy had 'won the palm of cereals', that it was grown in a number of places in Italy, but that the best (laudatissima) came from Campania ( $H N$ 18.109). The Campanians mixed this grain with a special chalk found between Pozzuoli and Naples that contributed to its remarkable white colour and fine grade. Augustus thought it important enough to pay 200,000 sesterces yearly to mine this chalk ( $H N$ 18.114). Thus it would make sense, if alicaria became an informal term for prostitute, for it to happen in Campania.

From the heart of Campania comes the last bit of evidence. A graffito from a small room in Pompeii reads as follows: Glycol halicaria (CIL 4.4001). The inscription appears just to the left of a list of agricultural items and foodstuffs with prices, including oil, straw, hay, daily rations, and bran (CIL 4.4000). Adams contends that this graffito supplies no context to suggest that halicaria means 'prostitute' and that it more likely means 'female dealer in alica'. ${ }^{9}$ Given the list in CIL 4.4000, this initially seems plausible, but there are a few problems with this argument. First, Glyco is a male name, and we would have to explain why he is designated as a female here. ${ }^{10}$ More significantly, there is another graffito in the room that suggests that the writer of Glyco halicaria was playing on a meaning of alicaria that must include 'prostitute'. In CIL 4.3999, a graffito described as directly above CIL 4.4000, we read: Glyco cunnum/ lingit a(ssibus) II. This declaration that Glyco performs cunnilingus for the

\footnotetext{
6 Adams (n. 5), 336.

7 All the other appearances of the word are later than Plautus. Unfortunately, the occurrence in Lucilius comes in a fragment which does not provide enough context to be useful.

8 Adams (n. 5), 336.

9 Adams (n. 5), 337.

${ }^{10}$ Cic. Ad. Brut. 14.2.1; Hor. Ep. 1.1.30; Petron. Sat. 45.8; Suet. Aug. 11.1.6; H. Solin, Die griechischen Personennamen in Rom (Berlin, 2003²), 2.945-6, includes forty-three examples of the name from inscriptions, most of which can be securely identified as male.
} 
price of two pennies mimics prostitution advertisements found elsewhere in Pompeii and provides exactly the sort of epigraphical context to confirm Festus' report.

How are we to understand the graffiti in this room? It would seem that someone was making fun of Glyco. While scholars accept many of these prostitution inscriptions as legitimate advertisements, ${ }^{11}$ cunnilingus almost invariably serves the function of invective in the Pompeian graffiti. ${ }^{12}$ Another inscription, a more obviously unreal and humorous bit of invective, adopts a similar approach by suggesting that the object of the attack, Maritimus, 'will perform cunnilingus for 4 pennies. Virgins welcome. Let us proceed to a city gate' (CIL 4.8939). ${ }^{13}$ The designation alicaria was an especially skilful piece of invective in that, it not only identified Glyco as a prostitute, it also characterized him as a woman. This would have been especially fitting from a male, Roman point of view, which looked upon the oral participant in the act of cunnilingus as playing an especially demeaning and passive role. Those who lowered themselves to perform such an act could hardly claim to be male. ${ }^{14}$ Finally, the term alicaria is appropriate and particularly clever in light of the archaeological context. The room seems to have been a shop where certain food items such as bran and daily rations could be purchased. Varone notes that it also served as an entranceway to a bakery. ${ }^{15}$ Thus, Glyco, whose 'advertisement' appears in the shop, is described with exactly the sort of word that would have been applied to a real prostitute who plied her trade in the vicinity of a bakery.

Gustavus Adolphus College, St Peter, Minnesota

M. PANCIERA

mpancier@gac.edu

doi:10.1017/S000983880700033X

11 T. A. J. McGinn, Prostitution, Sexuality, and the Law in Ancient Rome (Oxford, 1998), 267, n. 132 .

12 For an extended argument on this point see ch. 3 of M. Panciera, 'Sexual practice and invective in Martial and Pompeian inscriptions' (Diss., University of North Carolina, Chapel Hill, 2001).

${ }_{13}$ Maritimus cunnu( $m$ ) linget a(ssibus) IIII, virgines ammittit / perga [m]us al( $i$ ) qua po(rta?). The first line of this graffito is repeated in CIL 4.8940. W. Krenkel, 'Review of Erotica Pompeiana', Gnomon 69.6 (1997), 552-4, at 553, argues that ammittit can come from either abs-mitto or ad-mitto and thus it is also possible to translate this as 'he sends away virgins'.

14 A point Martial makes in 7.67 about the lesbian Philaenis who wrongly thinks it manly (virile) to perform cunnilingus on other women.

15 A. Varone, Erotica Pompeiana: iscrizioni d'amore sui muri di Pompei (Rome, 1994), 138, n. 242.

\section{ELEPHANTS AT RAPHIA: REINTERPRETING POLYBIUS 5.84-5*}

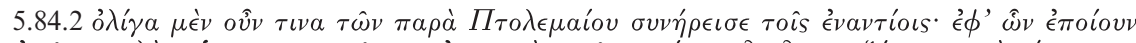

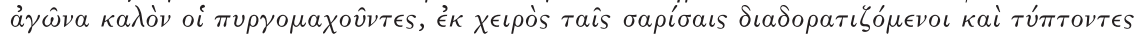

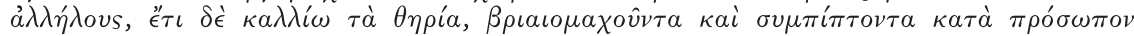

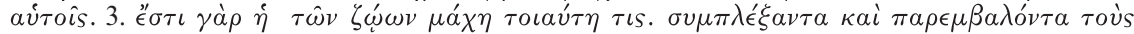

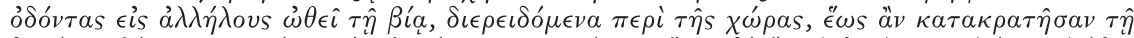

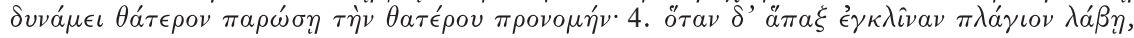

* I should like to thank $C Q$ 's anonymous referee for most useful advice. 